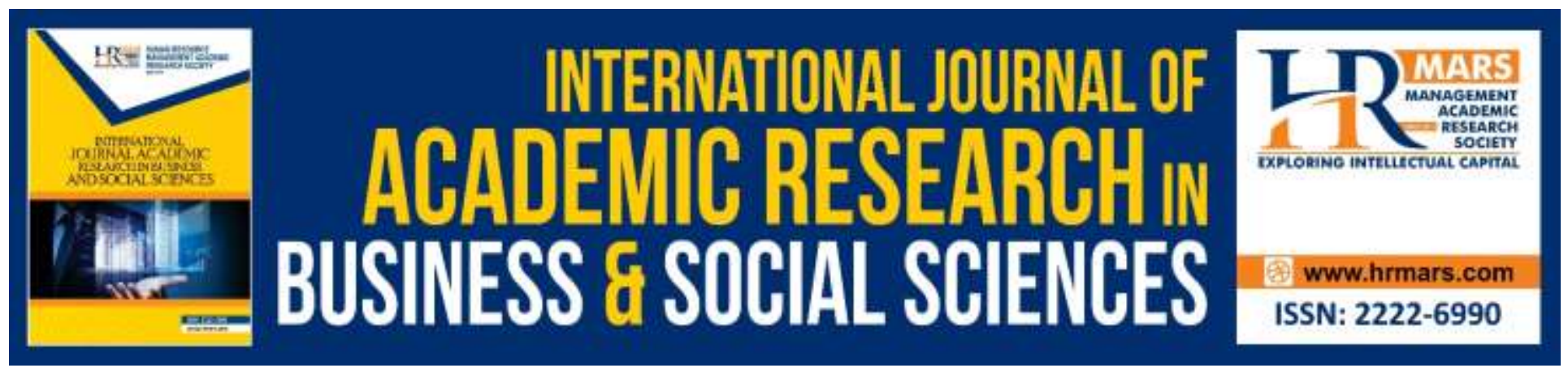

\title{
Experimental Theatre as a Method to Identify the Early Signs of Obsessive-Compulsive Disorder
}

\author{
Salman Alfarisi, Muhammad Fazli Taib Saearani, Sumathi Maniam, Herry \\ Rizal Djahwasi, Nurezlin Mohd Azib
}

To Link this Article: http://dx.doi.org/10.6007/IJARBSS/v10-i2/6861

DOI:10.6007/IJARBSS/v10-i2/6861

Received: 23 December 2019, Revised: 10 January 2020, Accepted: 23 January 2020

Published Online: 30 January 2020

In-Text Citation: (Alfarisi et al., 2020)

To Cite this Article: Alfarisi, S., Saearani, M. F. T., Maniam, S., Djahwasi, H. R., \& Azib, N. M. (2020). Experimental Theatre as a Method to Identify the Early Signs of Obsessive-Compulsive Disorder. International Journal of Academic Research in Business and Social Sciences, 10(2), 57-68.

Copyright: (C) 2020 The Author(s)

Published by Human Resource Management Academic Research Society (www.hrmars.com)

This article is published under the Creative Commons Attribution (CC BY 4.0) license. Anyone may reproduce, distribute, translate and create derivative works of this article (for both commercial and non-commercial purposes), subject to full attribution to the original publication and authors. The full terms of this license may be seen

at: http://creativecommons.org/licences/by/4.0/legalcode

Vol. 10, No. 2, 2020, Pg. 57 - 68

http://hrmars.com/index.php/pages/detail/IJARBSS

JOURNAL HOMEPAGE

Full Terms \& Conditions of access and use can be found at http://hrmars.com/index.php/pages/detail/publication-ethics 


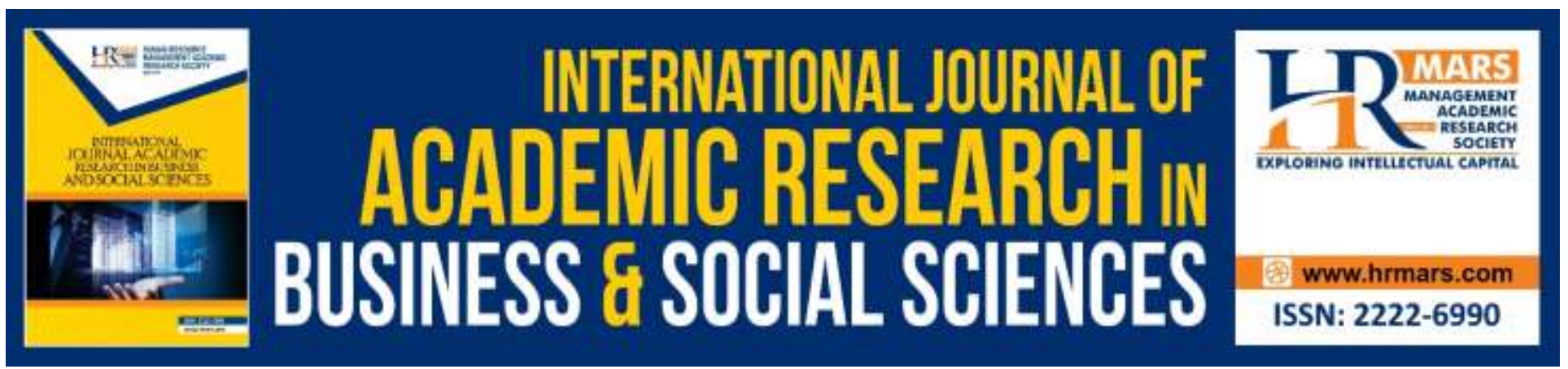

\title{
Experimental Theatre as a Method to Identify the Early Signs of Obsessive-Compulsive Disorder
}

\author{
Salman Alfarisi, Muhammad Fazli Taib Saearani, Sumathi Maniam \\ Department of Performing Arts, Faculty of Music and Performing Arts, Sultan Idris Education \\ University, Malaysia
}

\section{Herry Rizal Djahwasi, Nurezlin Mohd Azib}

Department of Music and Music Education, Faculty of Music and Performing Arts, Sultan Idris Education University, Malaysia

\begin{abstract}
This article addresses the process of experimental theatre performed among the community and also Obsessive-Compulsive Disorder (OCD) patients and the types of experimental theatre that are most suitable for identifying the step ladder of Obsessive-Compulsive Disorder (OCD). The study was conducted because, in essence, Obsessive-Compulsive Disorder (OCD) is a disease with a potential problem not only in Malaysia but also worldwide. Although this is so, when the issue of mental illness is raised, there are still individuals who do not understand the true state of an OCD patient, and some even think negatively about those who suffer from OCD mental illness. Society should play a role in reducing the negative perception of OCD patients. Of course, in this case, one of the ways to convey the strong message of understanding OCD patients is by performing experimental theatre in the community. In terms of the approach, a mini experimental theatre was performed based on the theatre of two worlds' concept developed by Peter Brook, combined with the application of symbolic interaction theory by Herbert Mead. Data collection was conducted by using qualitative methods to show the processes involved in the experimental theatre which should be tailored to the community level of ability and knowledge of OCD. So, based on the process of experimental theatre, it was found that various forms or genres, such as physical theatre, playback, surrealism, and realism. These genres appear which could assist the community in identifying the step ladder of the OCD mental illness. However of the four genres, the most appropriate is physical theatre after that playback theatre can also provide an adequate solution. Apart from that, these experimental theatres could also be used to help change people's views on mental illness and also make a positive impression on OCD patients in the community.
\end{abstract}

Keywords: Experimental Theatre, OCD, Community 
INTERNATIONAL JOURNAL OF ACADEMIC RESEARCH IN BUSINESS AND SOCIAL SCIENCES

Vol. 10, No. 2, Feb, 2020, E-ISSN: 2222-6990 @ 2020 HRMARS

\section{Introduction}

Najmuddin (2004) stated that OCD is a component related to obsessive and compulsive. Apart from that, Giddens (2009) said that neurological disorders are also present in obsessive and compulsive characteristics. Further, Rachman and de Silva (2009); Alqatamin (2018) argued that OCD has always been considered a neurotic disorder, for example, phobias and something that makes someone worry.

Furthermore, Pedrick and Hyman (2010) stated that OCD is a combination of obsession and compulsiveness that causes the patient to suffer from the mental disorder which delays the time to do anything, resulting in sadness and depression. This disorder also causes disruptions to their normal life, relationship with other people and also daily routine. Not only that, people with OCD experience a high degree of uncertainty or disruption that cannot be controlled by their own. (Tompkins, 2012; Haris@Harib, \& Yunus, 2018).

Referring to the above view, it can be seen that OCD is a type of anxiety disorder under the category of neurosis which involves obsession, compulsivity, or both. OCD patients feel pressured when negative things are always troubling their minds, causing them to perform their rituals over and over again, merely to relieve their anxiety. In addition, it is also stated that the fractions of OCD are obsessive and compulsive.

Najmuddin (2004) said that obsession is a component related to beliefs, thoughts, images, or impulses that are not logical and irrational. Giddens (2009), also stated that their obsession is about ideas, images, and impulses that often flutter in one's mind. Rachman and de Silva (2009) explained that obsession is an image or thoughts that are repeated, undesirable, disturbing, and an ongoing push.

Pedrick and Hyman (2010); Isaak, (2014) also stated that obsession is a continuous urge, ideas, images, or disturbing thoughts that cause feelings of anxiety and moodiness. Tompkins (2012) stated that obsession means repetition, continuity, the distraction of thoughts, images, or undesirable impulses. Deriving from the above various opinions on obsession, it can be concluded that it is a form of unpleasant distraction that is always disrupting the mind. Next Najmuddin (2004) also stated that compulsive behavior is one that is carried out repeatedly and abnormal, which causes unavoidable obsessive thoughts. Giddens (2009) also stated that a person's acts of retaliation against excessive doubt, which cause recurring behavior, is also known as compulsive.

Rachman and Silva (2009) asserted that compulsiveness is characterized as a behavior that is purposeful, meaningful, and intentional which makes a person feel compelled to repeat it again and again. According to Pedrick and Hyman (2010), compulsive refers to repetitive behavior, used as an effort to reduce the doubts and miseries that are caused by obsessive thoughts playing in one's mind. Besides, compulsiveness is also a deliberate behavior that sometimes causes a person to do it many times (Tompkins, 2012). That way, obsession can be judged as something that disturbs a person's mind inevitably so that it becomes the cause of enactment in terms of repetitive behavior until the patient is relieved. In general, it is observed that society still holds the perception that OCD mental illness groups do not need to be given a proper social environment in the community. This causes the patients to lose hope in themselves. Apart from that, people do not give their attention to OCD patients due to a lack of knowledge about the disease. Most cases of OCD in adults are caused by not being handled well in childhood. Thus, as stated by Durand and Barlow (2006), obsessions and compulsions can be positioned as a continuum, like most clinical features of anxiety disorders so that 
most OCDs are identified through medical methods. Therefore, because OCD is also a problem that involves social, it is deemed necessary to recognize it not solely using medical methods. In this context, theatre can be a choice approach, especially in the social function of theatre concerning the community. Furthermore, a mini experimental theatre can be the medium for people to recognize the early stages of OCD mental illness. By presenting the early signs of OCD disease through mini experimental theatre performance, the community can be exposed to symptoms of OCD disease, and help needed by the patients. This in return, will help the society to be aware of the illness, understand, and interact better with the OCD patients.

To find the relationship between OCD disease, society and theatre, this article uses the symbolic interaction theory by Herbert Mead. Azizi et al. (2005) stated that there are three main principles, firstly, humans acting on cases that have their meanings and interpretations. This is consistent with what was quoted by Evans (1970) in the context of experimental theatre. Next, the meaning of an event found in social interaction. And lastly, the process of interpretation, where the meaning is changed before it is used by humans to control any case. Besides, humans will exchange styles to adjust to the activities and behavior of others. The main thing in symbolic interaction theory according to Mulyana (2000) is communication or exchange of symbols which have been given a meaning.

Furthermore, experimental theatre refers to the concept theatre of two worlds as stated by Peter Brook, referring to the experience of theatre as an attempt to connect two realities, namely imagination and the everyday world as realities of the real audience (Mitter, 2002). The two worlds can be understood as the physical activity of the performers on different stages with the audience during the performances. But both of them meet in a situation called a game that provides a special experience. The situation is referred to by Peter Brook as The Shifting Point. Yudiaryani, (2005) stated that The Shifting Point is a game that produces a variety of truths that moves from one space to another. The various truths make the actors and viewers find many different perspectives.

\section{Objective}

1. To identify the forms of experimental theatre processes conducted among the community and OCD patients

2. To explore appropriate methods of experimental theatre to identify early signs of OCD disease.

\section{Methodology}

This article's research was based on a qualitative design. The data was obtained from informants and library sources, and written in descriptive form. The research was carried out by collecting data from interviews, observations, analysis of documents, and library techniques. After that, the data coding was done by organizing it into different categories to compile the concepts needed. Next, an analysis was carried out in detail to determine and ensure that the data will be in accordance with the research objectives.

The first step of the research was to communicate with OCD patients who were confirmed of having OCD, based on expert's advice by the doctors, as well as the patients' confession themselves, who openly acknowledged that they have OCD. From the results of the communication, the most appropriate technique decided was to choose the most suitable genre of the theatre to be applied to the participants involved. The participants also played the role of informants for the experimental 
mini-theatre before it was presented. After that, a series of mind and physical exercises were conducted based on research needs. These exercises were carried out for fourteen weeks with a total of eight exercises. Then, a small show was made to get reciprocity from the participants and the audience.

Workshops were conducted in Bangi and also in Kuala Lumpur, Malaysia. Lastly, feedback was obtained from the actors involved. This research involved 18 actors and 2 OCD patients.

\section{Results and Discussion}

\section{Theatre Workshop with OCD Theme}

To obtain information in accordance with the purpose of research, a theatre training workshop was conducted for several people. This theatre workshop aimed to obtain participants' level of knowledge on OCD. In addition, it also aimed to obtain their responses to OCD patients to understand their attitude and views after the workshop. The stages of the workshop can be seen as below:

\begin{tabular}{|c|c|c|c|}
\hline PHASE & DURATION & CONTENTS & OBSERVATION \\
\hline First & 8 hours & $\begin{array}{l}\text { Brainstorming with people } \\
\text { who participated in the } \\
\text { workshops. Deepen their } \\
\text { knowledge of OCD. Include } \\
\text { their views and experiences } \\
\text { of interacting with OCD } \\
\text { patients. }\end{array}$ & $\begin{array}{lr}\text { Only a small } \\
\text { number of people } \\
\text { understood } & \text { OCD } \\
\text { and had } & \text { prior } \\
\text { experience r in } \\
\text { interacting } & \text { with } \\
\text { OCD patients. } & \end{array}$ \\
\hline Second & 6 hours & $\begin{array}{l}\text { Make a simple acting } \\
\text { movement that mimics the } \\
\text { activity of OCD illness. These } \\
\text { movements were done } \\
\text { without emotions. }\end{array}$ & $\begin{array}{l}\text { The participants } \\
\text { had not felt } \\
\text { anything yet. OCD } \\
\text { had not been } \\
\text { properly } \\
\text { characterized. }\end{array}$ \\
\hline Third & 6 hours & $\begin{array}{l}\text { The acting movements } \\
\text { became a bit more difficult. } \\
\text { Emotions were involved so } \\
\text { that the participants would } \\
\text { not attempt to deny the } \\
\text { reality and situation of OCD. }\end{array}$ & $\begin{array}{l}\text { Participants began } \\
\text { to feel and } \\
\text { recognize the level } \\
\text { and type of OCD } \\
\text { disease. In addition, } \\
\text { their bodies felt } \\
\text { increasingly tired } \\
\text { after the } \\
\text { movements. The } \\
\text { contradiction } \\
\text { between the mind } \\
\text { and body began to } \\
\text { arise. }\end{array}$ \\
\hline Fourth & 8 hours & Creation & The feeling of pain \\
\hline
\end{tabular}


INTERNATIONAL JOURNAL OF ACADEMIC RESEARCH IN BUSINESS AND SOCIAL SCIENCES Vol. 10, No. 2, Feb, 2020, E-ISSN: 2222-6990 @ 2020 HRMARS

\begin{tabular}{|c|c|c|c|}
\hline & & $\begin{array}{l}\text { movements that were more } \\
\text { challenging by referring to } \\
\text { the activities of the OCD } \\
\text { patients. In this phase, they } \\
\text { were asked to feel every } \\
\text { movement. Their feelings } \\
\text { were on the verge of } \\
\text { accepting and rejecting } \\
\text { reality and it happened } \\
\text { continually to themselves, } \\
\text { feeling as if they were } \\
\text { experiencing the most } \\
\text { stressful moment. }\end{array}$ & $\begin{array}{lr}\text { was } & \text { getting } \\
\text { stronger. } & \text { Self- } \\
\text { resistance } & \text { was } \\
\text { getting louder. } & \text { The } \\
\text { pressure } & \text { was } \\
\text { almost } & \\
\text { uncontrollable. }\end{array}$ \\
\hline Fifth & 8 hours & $\begin{array}{l}\text { Acting movements increased } \\
\text { in difficulty level, heavier in } \\
\text { the sense that they required } \\
\text { great physical exertion. The } \\
\text { movements contrasted with } \\
\text { wishes and feelings. But } \\
\text { eventually, they tried to } \\
\text { accept this fact. }\end{array}$ & $\begin{array}{l}\text { The movement } \\
\text { began to be } \\
\text { enjoyed and } \\
\text { participants started } \\
\text { feeling relieved. }\end{array}$ \\
\hline Sixth & 9 hours & $\begin{array}{l}\text { Acting movements were more } \\
\text { difficult and heavy, requiring } \\
\text { greater physical exertion. The } \\
\text { movements still contrasted with } \\
\text { wishes and feelings. The OCD } \\
\text { fact was being understood and } \\
\text { accepted by the participants. } \\
\text { Participants encountered more } \\
\text { social interaction with others } \\
\text { until the end of the process. }\end{array}$ & $\begin{array}{l}\text { Participants had } \\
\text { increasingly felt } \\
\text { familiar with the pain } \\
\text { experienced by OCD } \\
\text { patients, and the } \\
\text { patients felt happy } \\
\text { for finding comrades } \\
\text { they could relate to. }\end{array}$ \\
\hline Seventh & 30 minutes & $\begin{array}{l}\text { A mini experimental theatre } \\
\text { was performed, following the } \\
\text { theme of OCD. }\end{array}$ & $\begin{array}{l}\text { Participants were in } \\
\text { high spirits upon } \\
\text { discovering this new } \\
\text { experience. }\end{array}$ \\
\hline Eighth & 2 hours & Postmortem: Getting feedback & $\begin{array}{l}\text { Participants felt } \\
\text { ready to volunteer } \\
\text { for OCD illness } \\
\text { awareness } \\
\text { campaigns to foster } \\
\text { good understanding } \\
\text { of OCD disease. }\end{array}$ \\
\hline
\end{tabular}

Table 1 Work flow and contents of the workshop with OCD theme (Source: Salman, 2018-2019) 
Referring to the table 1 work flow and contents of the workshop with OCD theme table above, it can be observed that there had been a significant development that occurred in the workshop's participants. The diagram showed that before the workshop was held, their lack of knowledge about OCD could gradually be improved which was positive in the situation, for OCD patients. In particular, they can recognize or identify the signs of OCD impacting on awareness and taking precautions on the OCD disease symptoms.

\section{Props as Medium of Imagination and Interaction}

During the processes in the theatre workshop, masks and dolls were used as props to help participants develop their imagination on the OCD disease. The 'world of imagination' act was created after they were observed to have understood better about OCD. Previously, they were asked to describe their character-play that was selected in accordance with the shape of the mask. After that, they helped to construct the story and its characters with a strong disposition relating to the characteristics portrayed by OCD disease. They were asked to explain the character of the mask chosen. Later, they were given help in arranging stories and strong characters, related to the characteristics of OCD. The next step was to show the results of the role that had been determined. In this context, they had become OCD patients and they had to reflect correctly on the OCD disease. This was intended to imagine the reality experienced by OCD patients. The 'world of imagination' OCD-based act was a symbolic interaction between the community and OCD patients. As stated by Charon (1979), the symbol is the object used in social interaction and communication determined by the people who use it.

The same thing applies when dolls were used as a tool for the community to have a better understanding of the experience of OCD patients. First of all, they gave an identity to the doll, both in psychological and sociological aspects. After that, they made connections between the construction of the doll's identity with the reality of OCD patients. The next step was building a symbolic interaction between the world of imagination and reality. In such situations, the community has built five symbolic interaction concepts referring to Blumer (in Veeger, 1985) in terms of the concept of self, actions, objects, social interactions, and also joint action. In other words, the community sees itself as an individual organism that performs actions based on interactions. Not only that, but they also see themselves as an object that is voluntarily moved by themselves to others as a form of social interaction to portray a symbolic manner of communication (Mulyana, 2000).
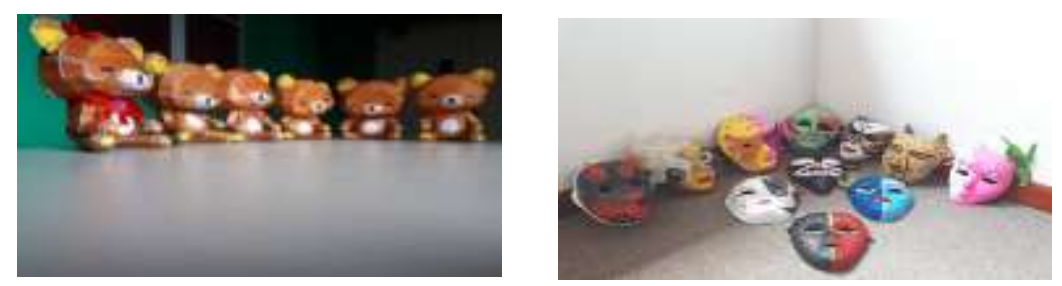

Figures 1 some character doll and figures 2 some mask characters used (Source: Zolkifli Abdullah's Sinographic Works, 2019)

Referring to the figures 1 above of some character doll and mask used, when used as performance equipment, these dolls and masks provide clearer clues where actors feel that they need to 
understand more deeply about what is experienced by OCD patients. Communication of thoughts and feelings that take place interactively during the process of preparation and performance of the mini-experimental theatre is a valuable experience that stems from the creative imagination of the actors (Hadi, 2012). That way, the value of the performance had more or less succeeded in removing the barrier between the actor and the OCD patients. Besides that, contexts of performance must also have a dramatic impact which further establishes the actor's relationship with their subject matter (Waluyo, 2007).

\section{Mini Experimental Theatre with the Theme: Repetitive Behaviors}

The most common OCD behavior that can be seen is exemplified in the act such as checking something repeatedly. For example, although the patient knows and is certain that the windows of his house have been closed, OCD- affected thought will always urge him or her to check the windows again repeatedly. Abramowitz, McKay, and Taylor (2008) stated that the act of checking something repeatedly without clear threats is a very confusing situation. Colley (2010) added that, besides checking the windows of the house, other actions that can be categorized into this type of OCD include opening and closing the door of the house repeatedly to make sure it has been locked, checking the gas in the kitchen, and switching off and on the lights. Referring to the case above, a mini experimental act was made as the following:

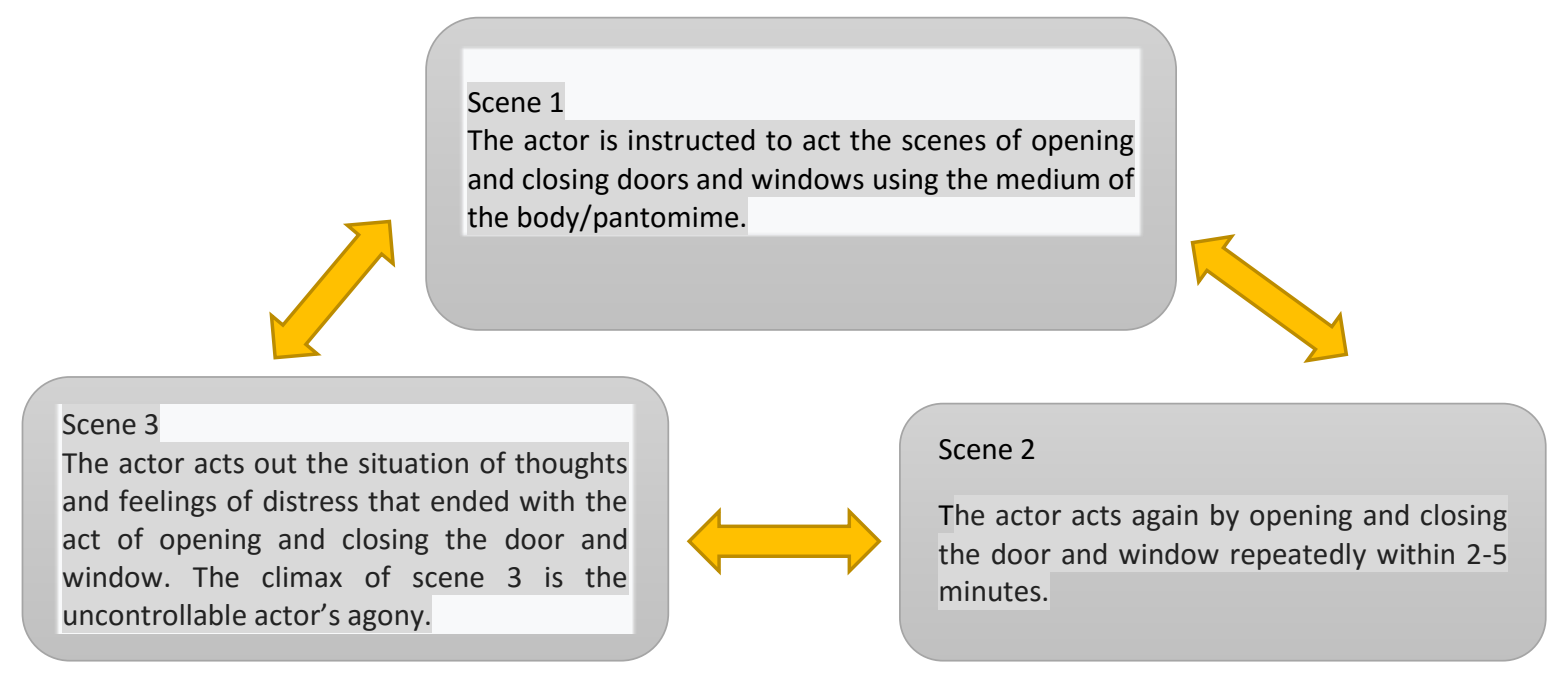

Figure 3 Mini experimental theatre act for OCD repetitive behaviors

(Source: Salman, 2018-2019)

Figure 3 above that is mini experimental theatre act for OCD repetitive behaviors shows that the actor was asked to act out a situation that illustrates the habits of OCD mental illness through fiction that had been developed based on the 'imaginary world of theatre concept' of Peter Brook. Then, the actor was asked to feel the reality experienced by the OCD patients to get the impression of Herbert Mead's symbolic interaction which led to a situation where the actors understood more on the thoughts and feelings of the OCD patients. In other words, the actors created social reality as a form of their interaction with OCD based on something that had been shaped in the mind individually 
INTERNATIONAL JOURNAL OF ACADEMIC RESEARCH IN BUSINESS AND SOCIAL SCIENCES Vol. 10, No. 2, Feb, 2020, E-ISSN: 2222-6990 @ 2020 HRMARS

(Soeprapto, 2002). Therefore, every social interaction prevailing in the imagination of actors with OCD patients is based on awareness that they are equally human (Fisher, 1986).

\section{Mini Experimental Theatre with the Theme: Cleanliness}

The aspect of cleanliness is an important issue that must be emphasized by every human being. So, if a person is very concerned about personal hygiene or environment by always making sure the situation is clean, that is not an odd matter. However, as stated by Connelly, Simpson and Petty (2006) if the act of cleaning is carried out excessively in the condition of a person being depressed so as to cause excessive fatigue, that is a characteristic that exists in people with OCD.

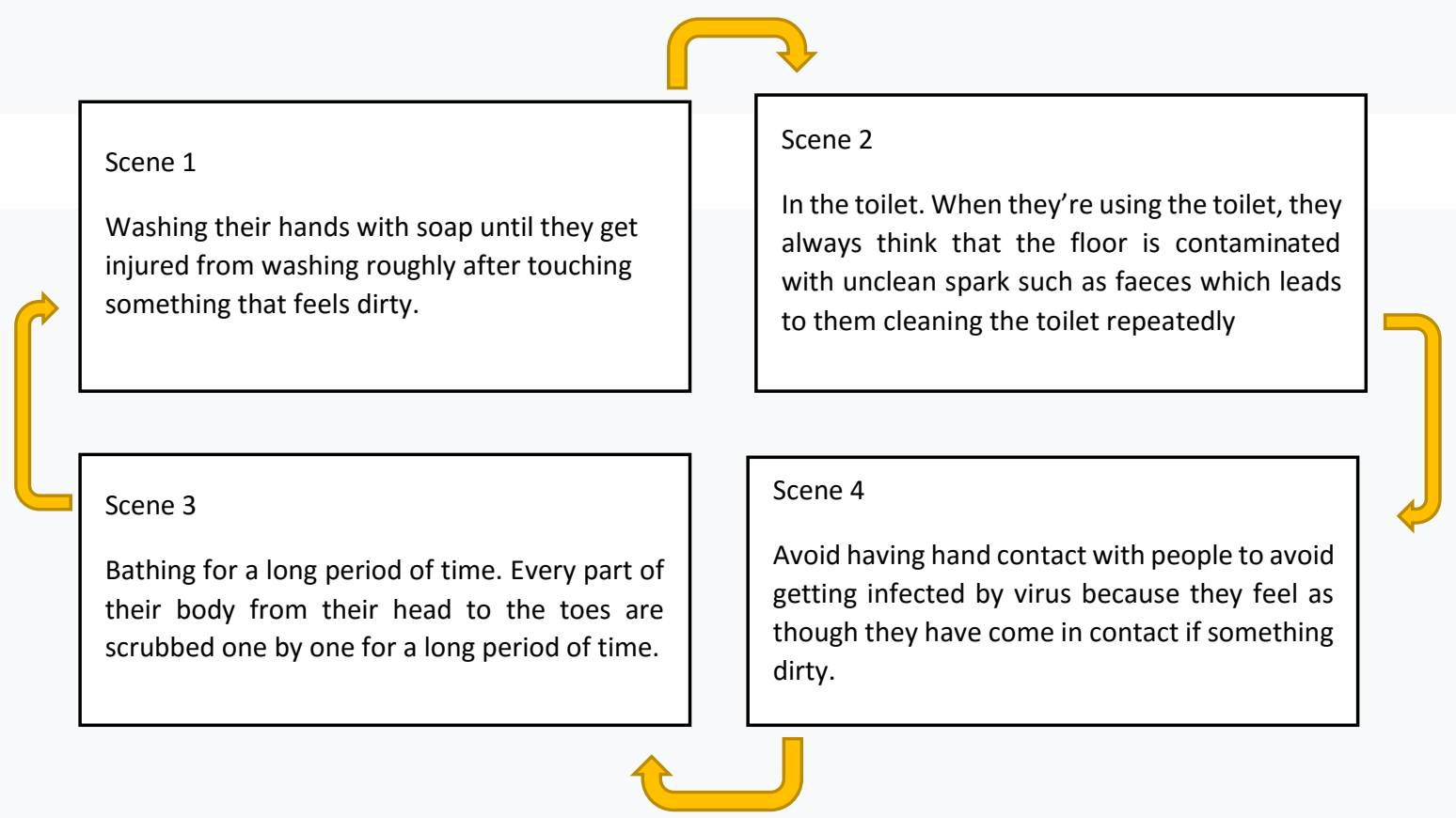

Figure 4 Mini experimental theatre act for OCD type hygiene

(Source: Salman, 2018-2019)

\section{Mini Experimental Theatre with the Theme: Orderly}

Mini experimental theatre proceeded with the actors acting out the theme of the Orderly type of OCD. Actors were asked to use masks so that they can communicate with OCD patients through the play. The imaginative communication was also a social interaction. Each of them seemed to communicate by referring to their respective activities but they had the same goal, which was creating social interaction (Charon, 1979).

This OCD category also portrays a person who emphasizes on great importance to perfection and order in each of the action by arranging something object repeatedly to satisfy the OCD thinking. Every item must be arranged carefully to obey the OCD criteria in their minds, such as positioning something in the same distance and must be straight, or following the color, size or category, and so 
INTERNATIONAL JOURNAL OF ACADEMIC RESEARCH IN BUSINESS AND SOCIAL SCIENCES

Vol. 10, No. 2, Feb, 2020, E-ISSN: 2222-6990 @ 2020 HRMARS

on. For example, McGrath (2007) explains that the patient may behave like walking in and out of a door in an even number calculation twice before entering the cubicle.

\section{Scene 1}

Arrange things repeatedly until it satisfies an OCD's brain. That things are to be arranged in a straight formation, the same distance between two objects. For example, a chair, pen, book, etc.

\section{Scene 2}

Classify and arrange things or objects according to their color, size or category.

Figure 5 Mini experimental theatre act for OCD orderly type

(Source: Salman, 2018-2019)

\section{Conclusion}

The contextual contribution of this study has opened awareness for OCD patients that in addition to the medical approach, they can also use theatre to find social space and even the desired healing process. Also, this study has brought theatre closer to social issues so that it has helped to find a more complex aesthetic and staging style of theatre. Referring to the explanation above, it can be concluded that the processes in the experimental theatre were conducted by following the suitability of the situation and level of community understanding of OCD mental illness due to the general lack of people's understanding of OCD. Secondly, a general explanation or discussion about OCD has to be carried out to get to corresponding ideas in the process of experimentation. Third, in general, these methods of experimental theatre can be used to strengthen people's understanding of OCD, particularly in identifying the early signs of the OCD disease. Last but not least, based on this experimental theatre processes, it was found that various forms or genres of theatre can be applied. Among them are physical theatre, playback, surrealism, even realism. In addition, this method was seen to be compatible with the level of understanding and also the community's ability to comprehend OCD.

\section{Acknowledgements}

This research is funded by the University Research Grant/GPU (2018-0109-107-01) from Universiti Pendidikan Sultan Idris (UPSI). We would like to express our gratitude and appreciation to the OCD patients as our informants and also to the workshop participants. 
INTERNATIONAL JOURNAL OF ACADEMIC RESEARCH IN BUSINESS AND SOCIAL SCIENCES

Vol. 10, No. 2, Feb, 2020, E-ISSN: 2222-6990 @ 2020 HRMARS

\section{Corresponding Author}

Muhammad Fazli Taib Saearani

Department of Performing Arts

Faculty of Music and Performing Arts

Sultan Idris Education University

35900, Tanjung Malim, Perak, Malaysia

Email: salman@fmsp.upsi.edu.my

\section{References}

Alqatamin, R. M. (2018). Capital Structure and CEO's Personal Characteristics: Evidence from Jordan, International Journal of Academic Research in Accounting, Finance and Management Sciences 8 (2): 113- 125.

Colley, A. (2010). Silent Rituals of the Mind: Living with OCD. London, United Kingdom: Chipmunkapublishing Ltd.

Durand, V. M., \& Barlow, D. H. (2006). Essentials of Abnormal Psychology. CA: Thomson Wadsworth. Hyman, B. M., \& Pedrick, C. (2010). The OCD Workbook: Your Guide to Breaking Free from ObsessiveCompulsive Disorder. Oakland, California: New Harbinger Publications.

Mulyana, D. (2000). Ilmu Komunikasi: Suatu Pengantar, Bandung: Remadja Rosdakarya.

Aubrey, F. B. (1986). Teori-teori Komunikasi: Perspektif Mekanistis, Psikologis, Interaksional, dan Pragmatis (Trimo, S., \& Rakhmat. J., Trans.). Bandung: Remaja Rosdakarya.

Najmuddin, H. (2004). Psikologi Ketenangan Hati. Kuala Lumpur, Malaysia: PTS.

Waluyo, H. J. (2007). Drama, Naskah, Pementasan dan Pengajarannya, Surakarta: LPP UNS.

Evans, J. R. (1970). Experimental Theatre: from Stanislavsky to Peter Brook. London: Studio Vista. Joel, M., Charon, J. M. (1979). Symbolic Interactionism, United States of America: Prentice Hall Inc.

Abramowitz, J. S., McKay, D., \& Taylor, S. (2008). Clinical Handbook of Obsessive-Compulsive Disorder and Related Problems. Maryland, Amerika Syarikat: JHU Press.

Veeger, K. J. (1985). Realitas Sosial, Refleksi Filsafat Sosial atas Hubungan Individu-Masyarakat dalam Cakrawala Sejarah Sosiologi. Jakarta: Gramedia.

Tompkins, M. A. (2012). OCD: A Guide for the Newly Diagnosed. Oakland, California: New Harbinger Publications.

McGrath, P. B. (2007). The OCD Answer Book: Professional Answers to More Than 250 Top Questions about Obsessive-Compulsive Disorder. Illinois, Amerika Syarikat: Sourcebooks, Inc.

Soeprapto, R. (2002). Interaksi Simbolik, Perspektif Sosiologi Modern. Yogyakarta: Averrpes Press dan Pustaka Pelajar.

Giddens, S. (2009). Obsessive-Compulsive Disorder. New York: The Rosen Publishing Group.

Mitter, S. (2002). Sistem Pelatihan Lakon. Stanilavsky, Brecht, Grotowski, Brook. Yogyakarta: Kerjasama MSPI dan arti.

Rachman, S. J., \& de Silva, P. (2009). Obsessive-Compulsive Disorder. Oxford, New York: Oxford University Press.

Connelly, S., Simpson, D. A., \& Petty, C. L. (2006). Psychological Disorder: Anxiety Disorders. New York: Chelsea House Publishers.

Hadi, Y. M. (2012). Seni Pertunjukan dan Masyarakat Penonton, Yogyakarta: Perpustakaan Nasional, Katalog Dalam Terbitan (KDT). 
INTERNATIONAL JOURNAL OF ACADEMIC RESEARCH IN BUSINESS AND SOCIAL SCIENCES

Vol. 10, No. 2, Feb, 2020, E-ISSN: 2222-6990 @ 2020 HRMARS

Haris@Harib, A. R. B., \& Yunus, A. M. (2018). Knowledge Management Implementation: An Experience of Perdana Leadership Foundation. International Journal of Academic Research in Progressive Education and Development, 7(3), 258-267.

Yudiaryani. (2005). Memahami Gaya dan Aplikasinya untuk Penciptaan Teater Masa Kini. Yogyakarta:

ISI Yoygyakarta.

Alfarisi, S., Saearani, M. F. T., Maniam, S., Djahwasi, H. R., \& Azib, N. M. (2020). Experimental Theatre as a Method to Identify the Early Signs of Obsessive-Compulsive Disorder.

International Journal of Academic Research in Business and Social Sciences, 9(2), 1-12.

Isaak, P. (2014). Creative writing activities and TPR plus: An implementation of foreign language development project to students with dyslexia. Multilingual Academic Journal of Education and Social Sciences, 2(1), 67-95. 